\title{
REMARKS ON THE MONOTONICITY AND CONVEXITY OF JENSEN'S FUNCTION
}

\section{YAng HuAng, YongtaO LI* AND Josip PeČARí}

Abstract. Let $x_{1}, x_{2}, \ldots, x_{n}$ be nonnegative real numbers. The Jensen function of $\left\{x_{i}\right\}_{i=1}^{n}$ is defined as $J_{s}(x)=\left(\sum_{i=1}^{n} x_{i}^{s}\right)^{1 / s}$, also known as the $L_{p}$-norm. It is well-known that $J_{s}(x)$ is decreasing on $s \in(0,+\infty)$. Moreover, Beckenbach [Amer. Math. Monthly, 53 (1946), $501-$ 505] proved further that $J_{s}(x)$ is a convex function on $s \in(0,+\infty)$. The goal of this note is two-fold. We first revisit the skillful treatment of the proof of Beckenbach, and then we simplify the proof slightly. Additionally, we give a new proof of the convexity of $J_{s}(x)$ by using the Hölder inequality, our proof is more succinct and short. On the other hand, we investigate a Jensen-type inequality that arised from Fourier analysis by Stein and Weiss. As a byproduct, the Hardy-Littlewood-Póya inequality is also included.

Mathematics subject classification (2010): 26D15.

Keywords and phrases: Jensen's inequality, Beckenbach, Hardy-Littlewood-Pólya, convexity.

\section{RE F ER ENC ES}

[1] S. Abramovich, G. FARID, J. PeČArić, More about Jensen's inequality and Cauchy's means for superquadratic functions, J. Math. Inequal. 7 (2013), no. 1, 11-24.

[2] M. AdAmeK, On a Jensen-type inequality for F-convex functions, Math. Inequal. Appl. 22 (2019), no. 4, 1355-1364.

[3] E. F. Beckenbach, An inequality of Jensen, Amer. Math. Monthly, 53 (1946) 501-505.

[4] E. F. Beckenbach, R. Bellman, Inequalities, Springer-Verlag, Berlin, 1961.

[5] D. Choi, M. KRnić, J. PeČARIĆ, More accurate classes of Jensen-type inequalities for convex and operator convex functions, Math. Inequal. Appl. 21 (2018), no. 2, 301-321.

[6] G. H. Hardy, J. E. Littlewood And G. Pólya, Inequalities, Combridge University Press, Combridge, 1934.

[7] J. L. W. V. JENSEN, Sur les fonctions convexes et les inegalites entre les valeurs moyennes, Acta Mathematica, 30 (1906) 175-193.

[8] S. Khalid, J. PeČArić, M. Praljak, 3 -convex functions and generalizations of an inequality of Hardy-Littlewood-Pólya, Glas. Math. Ser. III 48 (2013), no. 2, 335-356.

[9] S. Khalid, J. PeČarić, M. Praljak, On an inequality of I. Perić, Math. Commun. 19 (2014), no, $2,221-242$.

[10] N. LOVRIČEvić, D. PeČARIĆ, J. PeČArić, Monotonicity of the Jensen functional for $f$-divergences with applications to the Zipf-Mandelbrot law, Math. Inequal. Appl. 22 (2019), no. 4, 1427-1449.

[11] D. PeČARIĆ, J. PEČARIĆ, M. Rodić, On a Jensen-type inequality for generalized $f$-divergences and Zipf-Mandelbrot law, Math. Inequal. Appl. 22 (2019), no. 4, 1463-1475.

[12] A. PRIngsheim, Zur Theorie der ganzen transzendenten Funktionen Sitzungsberichte der mathematisch-physikalischen Klasse der Bayerischen Akademie, 32 (1902) 295-304.

[13] E. M. STEIn AND G. Weiss, Introduction to Fourier Analysis on Euclidean Spaces, Princeton University Press, Princeton, 1971.

[14] P. M. VASIĆ, J. PEČARIĆ, On the Jensen inequality for monotone functions I, Anal. Univ. Timisoara, 17 (1979), 95-104.

[15] F. Zhang, Matrix Theory: Basic Results and Techniques, 2nd edition, Springer, New York, 2011. 